\title{
MORPHOPHYSIOLOGICAL CHARACTERIZATION OF RHIZOBIA ISOLATED FROM WILD GENOTYPES OF THE COMMON BEAN
}

\author{
CARACTERIZAÇÃO MORFOFISIOLÓGICA DE RIZÓBIOS ISOLADOS DE \\ GENÓTIPOS SILVESTRES DE FEIJOEIRO-COMUM
}

\begin{abstract}
Fernanda Bueno SAMPAIO'; Adriano Moreira KNUPP² ${ }^{2}$ Eliana Paula FERNANDES ${ }^{3}$, Claudia Cristina Garcia MARTIN-DIDONET ${ }^{4}$, Enderson Petrônio de Brito FERREIRA ${ }^{5}$

1. Engenheira Agrônoma, Mestre, Universidade Federal de Goiás - UFG, Goiânia, GO, Brasil; 2. Analista, Doutor, Embrapa Arroz e Feijão, Santo Antônio de Goiás, GO, Brasil; 3. Professora, Doutora, Universidade Federal de Goiás, Goiânia, GO, Brasil; 4. Professora, Doutora, Universidade Estadual de Goiás, Anápolis, GO, Brasil; 5. Pesquisador, Doutor, Embrapa Arroz e Feijão, Santo Antônio de Goiás, GO, Brasil. enderson.ferreira@embrapa.br
\end{abstract}

\begin{abstract}
This study aimed to characterize, based on the morphology and on the use of carbon sources, rhizobial isolates obtained from nodules of wild common bean genotypes cultivated on soil samples from the states of Goiás, Minas Gerais and Paraná. Based on morphological and carbon source use, similarity matrixes were generated to perform clustering analysis based on the Jaccard index. A total of 523 isolates were obtained with the predominance of isolates that acidify the culture medium and showed fast growth. Isolates from the soils of Araucária and Prudentópolis produced a greater amount of mucus than those from Jussara, Nova Veneza, Uberlândia and Unaí soils. The rhizobia isolates obtained from soils of Goiás and Minas Gerais showed greater phenotypic diversity than those from the soils of Paraná. Analysis based on the use of different carbon sources revealed that rhizobia isolates obtained from soils of Goiás have higher metabolic diversity. Overall, the most part of isolates grouped with the reference strains, especially with the Rhizobium tropici and $R$. freirei strains used as inoculants for the common bean.
\end{abstract}

KEYWORDS: Phaseolus vulgaris. BNF. Morphological characterization. Carbon sources use.

\section{INTRODUCTION}

The common bean (Phaseolus vulgaris L.) shows great social and economic importance worldwide (BUILES et al., 2011), in addition to being the main source of protein for the poor population. Brazil is the third common bean producer of the world (FAO, 2015), with a harvested area of 2.94 million hectares and grain yield of $1070 \mathrm{~kg} \mathrm{ha}^{-1}$ (IBGE, 2015). This crop is able, when associated with soil bacterial known as rhizobia, to perform the biological nitrogen fixation (BNF), which takes place on specialized structures named nodules. The atmospheric nitrogen $\left(\mathrm{N}_{2}\right)$ is reduced to ammonium $\left(\mathrm{NH}_{3}\right)$, being catalyzed by the enzyme complex nitrogenase (HUNGRIA et al., 1997).

The obtaining and selection processes of efficient and well adapted rhizobia for the local conditions are essential to improve the efficiency of $\mathrm{BNF}$ on the common bean. According to Vargas and Hungria (1997), studies about the host-specificity of rhizobia strains obtained from the common bean, carried out under Cerrado conditions, provided good information about the amplitude of adaptation of local native rhizobia to a wide range of hosts. This same approach can be applied to other producing regions of the common bean.
On the other hand, few of the plant diversity available on the germplasm bank are exploited for the bacterial trapping. In this way, the use of the common bean wild genotypes as trapping plant can be an important factor to obtain high bacterial diversity, since different cultivars of a same plant species can promote a direct effect on microbial diversity of the rhizosphere (FERREIRA et al., 2008).

The selection process of $\mathrm{N}$-fixing bacteria is compounded by many steps leading to the reduction of bacterial isolates to be tested under field conditions. Among these steps, the selection based on morphophysiological parameters allows us to select isolates very close to those used as commercial inoculants. Thus, this work aimed to obtain and to characterize based on morphophysiological parameters, rhizobia isolates from soils of Goiás, Minas Gerais and Paraná states cultivated with wild genotypes of the common bean.

\section{MATERIAL AND METHODS}

\section{Origin of soil samples}

Soil samples were collected at $0-0.20 \mathrm{~m}$ widths on commercial production areas in the municipalities of Jussara (15'51'54”S, $\left.50^{\circ} 52^{\prime} 05^{\prime \prime} \mathrm{W}\right)$ and Nova Veneza $\left(16^{\circ} 22^{\prime} 15^{\prime} \mathrm{S}\right.$, $49^{\circ} 19^{\prime} 23^{\prime} \mathrm{W}$ ) in the state of Goiás; in Unaí 
(16 21'27'S, 46 $\left.54^{\prime} 22^{\prime \prime} \mathrm{W}\right)$ and Uberlândia $\left(18^{\circ} 55^{\prime} 08^{\prime \prime} \mathrm{S}, 48^{\circ} 16^{\prime} 37^{\prime \prime} \mathrm{W}\right)$ in the state of Minas Gerais and; in Araucária $\left(25^{\circ} 32^{\prime} 22^{\prime \prime} \mathrm{S}\right.$,

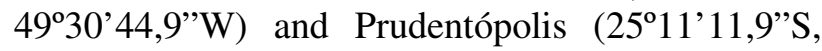

$51^{\circ} 00^{\prime} 23^{\prime}$ W) in the state of Paraná. Soil chemical characteristics were determined according to Embrapa (1997) and are shown in Table 1.

Table 1. Chemical characteristics of the soils used to obtain rhizobia isolates.

Site

$$
\begin{array}{lllllllllllllll}
\mathrm{pH} & \text { O.M. } & \mathrm{P} & \mathrm{K} & \mathrm{Ca} & \mathrm{Mg} & \mathrm{Al} & (\mathrm{H}+\mathrm{Al}) & \mathrm{Cu} & \mathrm{Zn} & \mathrm{Fe} & \mathrm{Mn} & \text { Clay } & \text { Silt } & \text { Sand }
\end{array}
$$

\begin{tabular}{lcccccccccccccccc} 
& \multicolumn{1}{c}{$\mathrm{In} \mathrm{H}_{2} \mathrm{O}$} & $\mathrm{g} \mathrm{kg}^{-1}$ & \multicolumn{1}{c}{$\mathrm{mg} \mathrm{dm}^{-3}$} & \multicolumn{4}{c}{$\mathrm{mmol}_{\mathrm{c}} \mathrm{dm}^{-3}$} & \multicolumn{3}{c}{$\mathrm{mg} \mathrm{dm}^{-3}$} & \multicolumn{5}{c}{$\mathrm{g} \mathrm{kg}^{-1}$} \\
\hline Jussara & 6.4 & 23.3 & 50 & 119 & 9 & 3 & 0 & 5 & 1.7 & 0.6 & 24 & 27 & 140 & 2 & 858 \\
Nova Veneza & 4.8 & 11.1 & 2.2 & 69 & 23 & 9 & 2 & 50 & 5.8 & 8.5 & 23 & 31 & 620 & 62 & 318 \\
Unaí & 6.4 & 31.1 & 25.3 & 86 & 27 & 20 & 0 & 15 & 0.8 & 41.5 & 25 & 28 & 320 & 122 & 558 \\
Uberlândia & 6.7 & 10.6 & 30 & 56 & 17 & 11 & 0 & 5 & 2 & 21.3 & 26 & 14 & 220 & 62 & 718 \\
Araucária & 6.4 & 25.5 & 72 & 237 & 32 & 18 & 0 & 15 & 1 & 3.5 & 31 & 34 & 460 & 82 & 458 \\
Prudentópolis & 5.2 & 63.2 & 18.2 & 367 & 40 & 20 & 2 & 112 & 1.3 & 5.1 & 32 & 39 & 460 & 222 & 318 \\
\hline
\end{tabular}

O.M.= organic matter

\section{Rhizobia isolation}

To obtain the rhizobia isolates, 11 wild genotypes of the common bean showing different morphological characteristics and origin, were chosen (Table 2).

The seeds of each wild genotype of the common bean were placed on moistened sterile germ test paper and incubated $\left(25^{\circ} \mathrm{C}, 24-36 \mathrm{~h}\right)$ for pre-germination. Two seedlings of each wild genotype were transplanted into $3 \mathrm{~L}$ pots containing soil from each state, and for each one, two pots were conducted under greenhouse condition. 30 days after the transplantation, the roots of the plants were carefully removed from the pots, washed and the nodules were removed and kept for a maximum period of one week, in sealed flasks containing silica gel.

The isolation of bacteria was performed using 10 nodules of the each common bean wild genotype. The nodules were randomly selected and rehydrated with autoclaved water. Then the nodules were surface disinfected $(70 \%$ ethanol, $30 \mathrm{sec}$; sodium hypochlorite 5\%, $3 \mathrm{~min} ; 10$ successive washes in autoclaved water). Then the nodules were macerated and scattered in Petri dishes containing Yeast Mannitol Agar (YMA) culture medium (Fred \& Waksman 1928), according to Hungria (1994). Petri dishes were kept at $28{ }^{\circ} \mathrm{C}$ until the appearance of colonies. Simple colonies were transferred to other Petri dishes containing the same culture medium and incubated again, to obtain pure cultures.

\section{Morphological characterization of rhizobia isolates}

Morphological characterization of isolates and the standard strains of Rhizobium tropici (SEMIA 4077 and SEMIA 4080), $R$. freirei (SEMIA 4088), $R$. leguminosarum bv. phaseoli (BR266, BR351 and BR281) and R. multihospitium (R82) was carried out in Petri dishes containing YMA medium with bromothymol blue as indicator (Fred \& Waksman 1928). The characterization was performed taking into account the $\mathrm{pH}$ of the culture medium (acidic and neutral), colony size (1-2 mm> $2 \mathrm{~mm}$ ), growth speed (fast $=<2$ days and slow $=>$ two days) colony color (orange, yellow, white and cream), mucus quantity (few, regular and high) and colony appearance (heterogeneous and homogeneous).

\section{Carbon source use by rhizobia isolates}

The characterization based on the use of different carbon sources by isolates and the standard strains of Rhizobium tropici (SEMIA 4077 and SEMIA 4088), $R$. freirei (SEMIA 4080), $R$. leguminosarum bv. phaseoli (BR266, BR351 and BR281) and R. multihospitium (R82) was carried out with 10 carbon sources: sucrose, glucose, malic acid, maleic acid, nicotinic acid, inositol, sorbitol, arabinose, fructose and glycerol. The isolates and 
standard strains were incubated under stirring (150 $\mathrm{rpm}, 28{ }^{\circ} \mathrm{C}, 48 \mathrm{~h}$ ) in penicillin tubes containing 5 $\mathrm{mL}$ of liquid YMA medium. After each isolate has grown, each one was transferred to a Petri dish containing YMA medium prepared with the different carbon sources. Then they were incubated at $28{ }^{\circ} \mathrm{C}$. After $48 \mathrm{~h}$ and, followed by a period of 96 $\mathrm{h}$ of growth, bacterial growth was checked out.

Table 2. Morphological characteristics and origin place of wild genotypes of the common bean used as trapping plants.

\begin{tabular}{|c|c|c|c|c|}
\hline \multirow{2}{*}{ Genotype } & \multirow{2}{*}{$\begin{array}{c}\text { Seed } \\
\text { Morphology }\end{array}$} & \multirow{2}{*}{$\begin{array}{l}{ }^{1} 100 \text { seeds } \\
\text { weight }(g)\end{array}$} & \multicolumn{2}{|c|}{${ }^{1}$ Genotype origin } \\
\hline & & & (District/Country) & (Latitude; Longitude) \\
\hline G23499A & 0 & 25.2 & Mara/Peru & $13^{\circ} 52^{\prime} \mathrm{S} ; 72^{\circ} 04^{\prime} \mathrm{W}$ \\
\hline G23490 & & 40.0 & Curpahuasi/Peru & $13^{\circ} 28^{\prime} \mathrm{S} ; 72^{\circ} 28^{\prime} \mathrm{W}$ \\
\hline G23500A & & 24.0 & Mara/Peru & $13^{\circ} 52^{\prime} \mathrm{S} ; 7^{\circ} 04^{\prime} \mathrm{W}$ \\
\hline G12912 & $\theta$ & 14.0 & Cuerámaro/Mexico & $20^{\circ} 36^{\prime} \mathrm{N} ; 101^{\circ} 43^{\prime} \mathrm{W}$ \\
\hline G23475 & 0 & 3.0 & n.i/Mexico & n.i \\
\hline G12858 & 青 & 8.0 & San Rámon/Peru & $11^{\circ} 13^{\prime} \mathrm{S} ; 75^{\circ} 28^{\prime} \mathrm{W}$ \\
\hline G23460 & 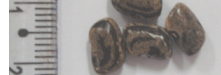 & 24.8 & Mara/Peru & $13^{\circ} 52^{\prime} \mathrm{S} ; 72^{\circ} 04^{\prime} \mathrm{W}$ \\
\hline G12904 & & 16.0 & Cuerámaro/Mexico & $20^{\circ} 36^{\prime} \mathrm{N} ; 101^{\circ} 43^{\prime} \mathrm{W}$ \\
\hline PHA VUL 8169B & $\theta$ & n.i & n.i & n.i \\
\hline PHA VUL 8141 & & n.i & n.i & n.i \\
\hline PHA VUL 8122 & 金 & n.i & n.i & n.i \\
\hline
\end{tabular}

${ }^{1}$ Source: CIAT (2015). n.i: no information.

\section{Statistical analysis}

Morphological and carbon source use data were, separately, converted into binary matrixes using 0 (zero) for the absence and one (1) for the presence of the characteristic. The matrixes were analyzed using NTSYS-pc software, version 1.8, to generate similarity dendrograms using Jaccard as the similarity coefficient and UPGMA
(Unweighted Pair Group Method with Arithmetic Mean) as the clustering method.

\section{RESULTS AND DISCUSSION}

\section{Obtaining rhizobia isolates}

A total of 523 rhizobia isolates were obtained of which 145, 208 and 170 were from 
Goiás, Minas Gerais and Paraná states, respectively. About $40 \%$ of the isolates was obtained from Minas Gerais soils, while the states of Parana and Goiás contributed with 32 and $28 \%$ of the isolates, respectively. Among the wild genotypes of the common bean, the largest numbers of isolates (63, 63 and 57) were obtained using the genotypes G23500A, G23490 and G23460, respectively, as trapping plants while the lowest number of isolates (42, 36 and 26) were obtained using the genotypes PHA VUL 8169B, 8141 PHA VUL and VUL PHA 8122 , respectively as trapping plants.

\section{Morphological characterization of rhizobia isolates}

Considering the morphological parameter, most of the isolates were able to acidify the culture medium and showed colony size $>2 \mathrm{~mm}$, fast growth, yellow color, regular mucus production and heterogeneous appearance (Table 2). All those characteristics are common among bacteria belonging to the genus Rhizobium (PINTO et al., 2007; MARQUINA et al. 2011; DALL'AGNOL et al. 2013).

Table 2. Number of rhizobia isolates obtained showing each morphological characteristic.

\begin{tabular}{lcc}
\hline Parameter & Morphological characteristic & Number of isolates \\
\hline \multirow{2}{*}{ HH } & acid & 415 \\
& neutral & 108 \\
\hline \multirow{2}{*}{ Colony size (mm) } & $>2$ & 373 \\
\multirow{2}{*}{ Growth velocity } & $1-2$ & 150 \\
\hline \multirow{4}{*}{ Colony color } & fast & 491 \\
& slow & 32 \\
\hline \multirow{2}{*}{ Mucus quantity } & orange & 20 \\
& yellow & 289 \\
\hline \multirow{2}{*}{ Colony appearance } & white & 7 \\
& cream & 207 \\
\hline
\end{tabular}

Among the isolates obtained from soil samples from Goiás, most of those acidified the culture medium, formed colonies $>2 \mathrm{~mm}$, showed fast growth, yellow coloring, few quantity of mucus and heterogeneous appearance (Figure 1A).

Regarding the isolates obtained from soil samples from Minas Gerais, most acidified the culture medium, formed colonies $>2 \mathrm{~mm}$, showed fast growth, yellow color, regular amount of mucus and heterogeneous appearance (Figure 1B).

For Paraná soils most of the isolates showed acid $\mathrm{pH}$, colonies with size $>2 \mathrm{~mm}$, fast growth, yellow color, produced high amount of mucus and heterogeneous appearance (Figure 1C).
The change in $\mathrm{pH}$ of YMA culture medium is a characteristic commonly used for the differentiation of genera of $\mathrm{N}$-fixing bacteria. Bacteria belonging to the genus Rhizobium have the property to acidify the culture medium, while Azorhizobium and Bradyrhizobium alkalize it (COUTINHO et al . 1999). This indicates that most of isolates obtained in this study, regardless of soil origin, have characteristics similar to those of Rhizobium genus, due mainly to the acidity of the culture medium and displaying fast growth, as well as other features like colonies with a diameter $>2$ $\mathrm{mm}$ and high mucus production (PINTO et al., 2007; MARQUINA et al. 2011; DALL'AGNOL et al. 2013). 
A

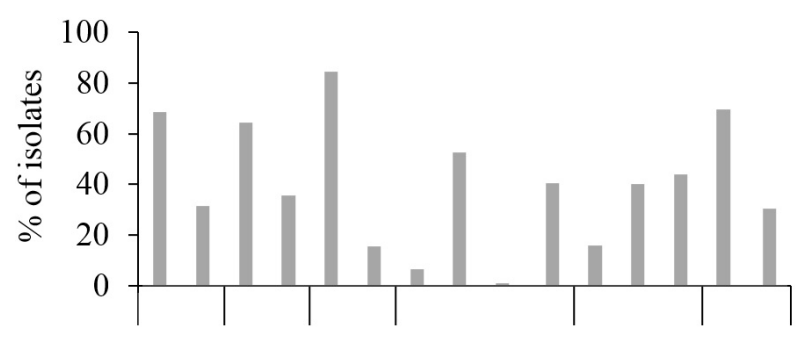

B

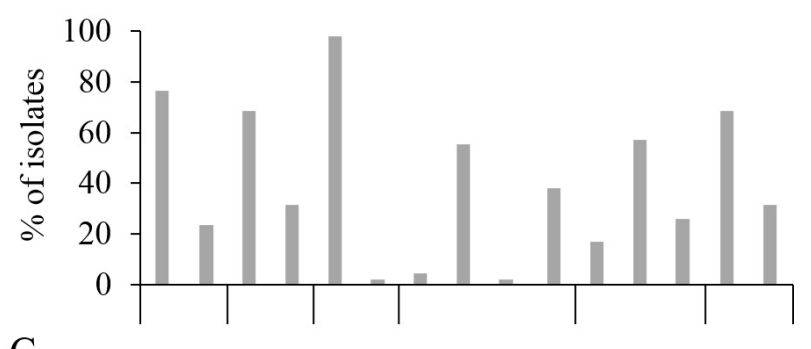

$\mathrm{C}$

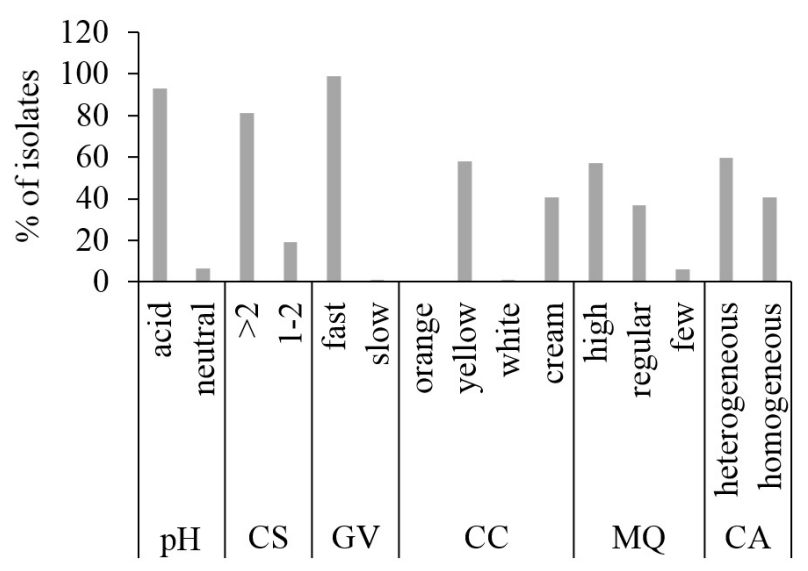

Figure 1. Percentage distribution of rhizobia isolates obtained from nodules of wild genotypes of the common bean cultivated in soil samples from Goiás (A), Minas Gerais (B) and Paraná (C) states. pH of culture medium $(\mathrm{pH})$, colony size $(\mathrm{CS})$, growth velocity $(\mathrm{GV})$, colony color $(\mathrm{CC})$, mucus quantity (MQ) and colony appearance (CA).

Nevertheless, high morphological diversity was observed among the obtained isolates, whereas the isolates showed unusual characteristics for the genus Rhizobium, such as neutral $\mathrm{pH}$, slow growth and small production of mucus (Figure 1). High morphological diversity among the common bean rhizobia isolates has been reported in Brazil (HUNGRIA et al. 2000; MOSTASSO et al. 2002; OLIVEIRA et al. 2011), reinforcing reports about the promiscuity of the common bean to establish association with the rhizobia soil community (OLIVEIRA et al. 2011).

\section{Use of carbon sources by rhizobia isolates}

Based on morphological characteristics; 76, 99 and 55 isolates were selected from the soils of Goiás, Minas Gerais and Paraná, respectively, for evaluation regarding the use of carbon sources.
The cluster analysis based on carbon source use by the isolates obtained from soil samples from the municipalities in the state of Goiás and the standard strains, showed the formation of 10 different groups at $55 \%$ of similarity. The most numerous group (G1) was formed by $88 \%$ of the isolates and by the standard strains, except the standard strain BR281 of $R$. leguminosarum bv. phaseoli (Figure 2).

The isolates JPrG7A5, JPrG8A3 and JPrG8A6 showed a $100 \%$ similarity with the standard strains BR266 and BR351 of $R$. leguminosarum bv. phaseoli and with the standard strain R82 of $R$. multihospitium. On the other hand, isolates JPrG10A1, JPrG3A4, JPrG7A2, NVSG2A4, NVSG6A2, NVSG2A1 and NVSG7A9 showed a $100 \%$ similarity with the standard strains of $R$. tropici (SEMIA 4077) and $R$. freirei (SEMIA 4080). 
The isolates JPrG10A8, JPrG1A1, JPrG5A7, JPrG6A8, NVSG11A3, NVSG1A1, NVSG2A6, NVSG3A4, NVSG4A5 and NVSG8A9 showed a $100 \%$ similarity with the standard strain SEMIA
4077 of $R$. tropici. Also, the isolate JPrG3A3 showed a $75 \%$ similarity with the standard strain BR281 of R. leguminosarum bv. phaseoli (Figure 2).

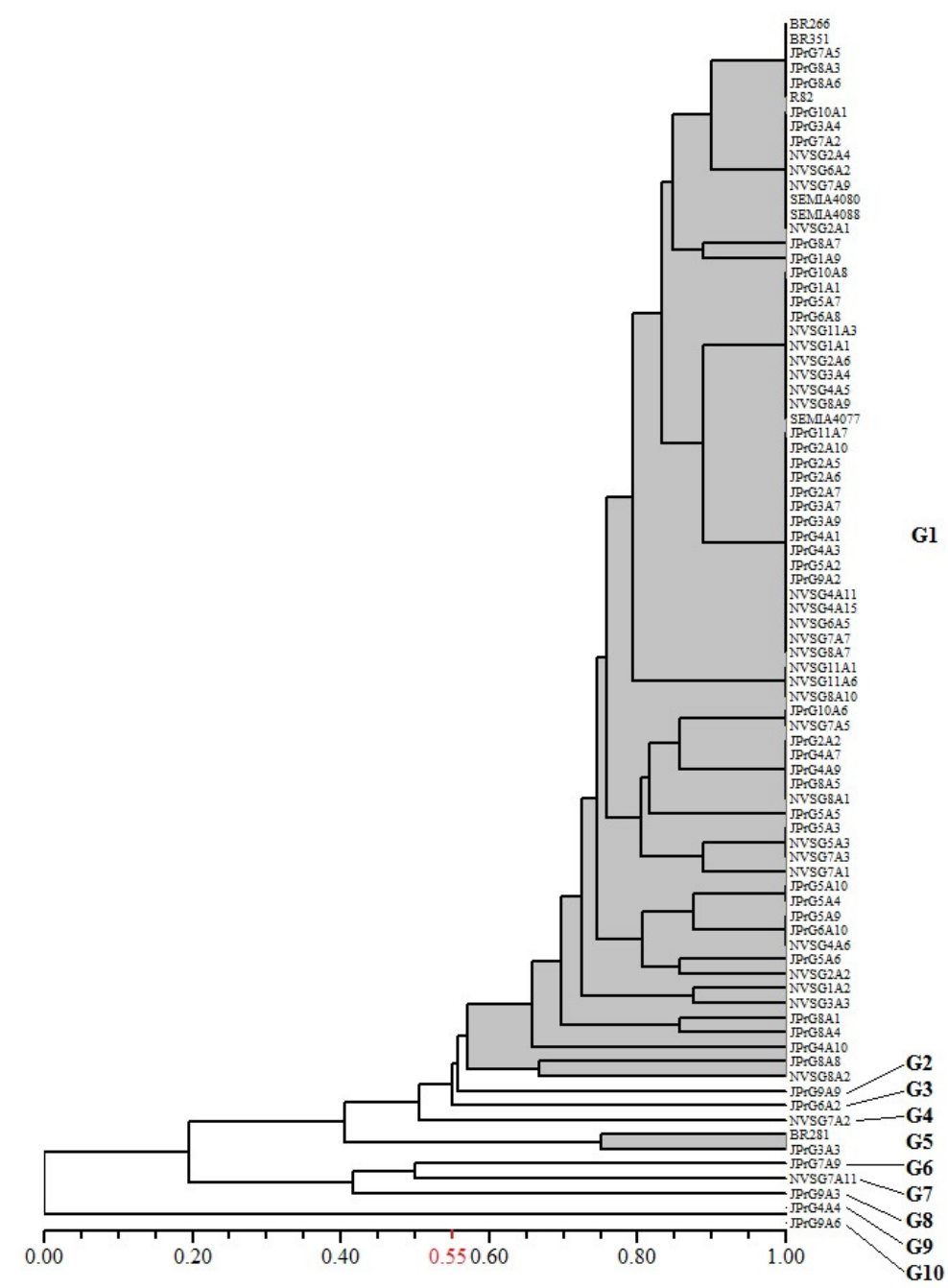

Figure 2. Similarity dendrogram constructed using Jaccard as similarity coefficient and UPGMA as grouping method, with basis on the use of different carbon sources by 76 rhizobia isolates obtained from soil samples of Goiás state.

Groups G2, G3 and G4 were formed by isolates with a 40 to $50 \%$ similarity with the standard strains, whereas G6 to G10 were formed by isolates with less than a $20 \%$ similarity with these standard strains (Figure 2).

For the isolates from Minas Gerais soils, cluster analysis revealed the formation of 7 groups with a similarity of up to $55 \%$ (Figure 3 ). The G5 group was formed with about $92 \%$ of the tested isolates and the standard strains, except for the BR281 strain of $R$. leguminosarum bv. phaseoli. In this group, 34 isolates had a $100 \%$ similarity with the standard strain SEMIA 4077 of $R$. tropici and 12 isolates were $100 \%$ similar to the standard strains SEMIA 4080 of $R$. freirei and SEMIA 4088 of $R$. tropici (Figure 3).
Also in the G5 group, the isolates UbAlG3A3, UbAlG6A3, UnPaG3A9 and UnPaG6A2 showed a $100 \%$ similarity with the standard strains BR266 and BR351 of $R$. leguminosarum bv. phaseoli and with the standard strain R82 of R. multihospitium (Figure 3).

The standard strain BR281 of $R$. leguminosarum bv. phaseoli grouped between G1 and G3 and G4, showing about 32\% of similarity with the isolates of these groups. The isolates UnPaG6A9 and UnPaG4A6 showed the lowest similarity in relation to the standard strains, forming the groups G6 and G7 (Figure 3). 


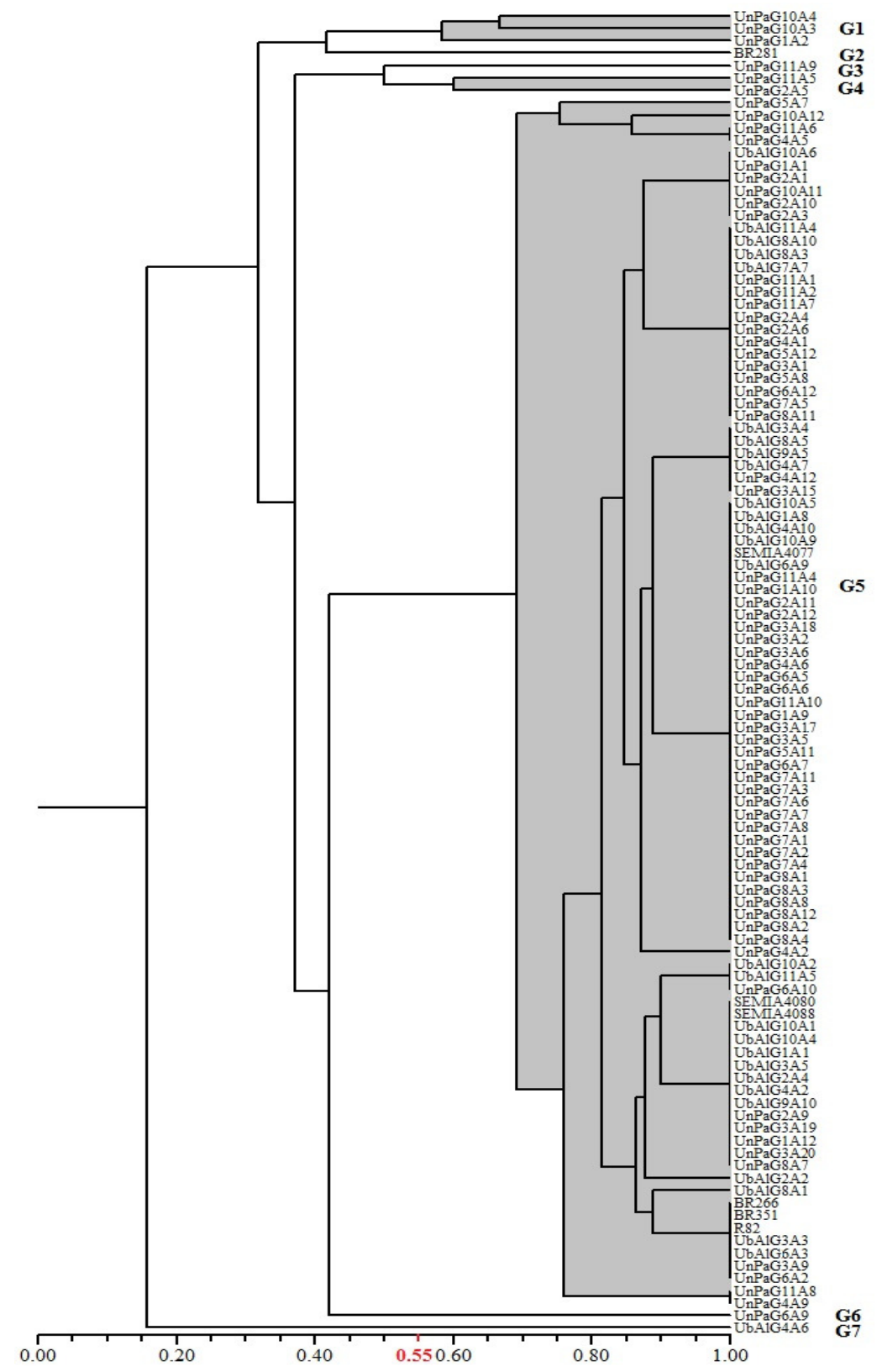

Figure 3. Similarity dendrogram constructed using Jaccard as similarity coefficient and UPGMA as grouping method, with basis on the use of different carbon sources by 99 rhizobia isolates obtained from soil samples of Minas Gerais state.

For isolates from Paraná soils, cluster analysis revealed the distribution of bacteria in five different groups, formed with about a 55\% similarity (Figure 4).

The groups G1, G2 and G3 were formed by the isolates ALSG1A7, PCG8A2 and PCG10A6, the latter showed a $100 \%$ similarity with the standard strain BR281 of $R$. leguminosarum bv. phaseoli. The group G4 was formed by the other standard strains and $91 \%$ of tested isolates. Within the group G4, 27 isolates were $100 \%$ similar to the standard strains SEMIA 4080 of $R$. freirei and SEMIA 4088 of $R$. tropici. Also, 13 other isolates showed a $100 \%$ similarity with the standard strain SEMIA 4077 of
R. tropici. In addition, 7 isolates showed a $100 \%$ similarity with the standard strains BR266 and BR351 of $R$. leguminosarum bv. phaseoli and with the standard strain R82 of $R$. multihospitium (Figure $4)$.

According to Castellane and Lemos (2007), strains of Rhizobium genus are fast growing bacteria, and use a variety of carbohydrates as carbon source, such as pentoses, hexoses, polyphenols, organic acids, disaccharides and polysaccharides. The strains of the species $R$. tropici and $R$. freirei have a great ability to use carbon sources, the latter of which has relatively lower capacity (DALL'AGNOL et al. 2013). The results 
presented in our study corroborate these authors and indicate that many of the tested isolates have characteristics very similar to those showed by the standard strains of $R$. tropici (SEMIA 4077 and SEMIA 4088) and $R$. freirei (SEMIA 4080) used in Brazil as commercial inoculant for common bean.

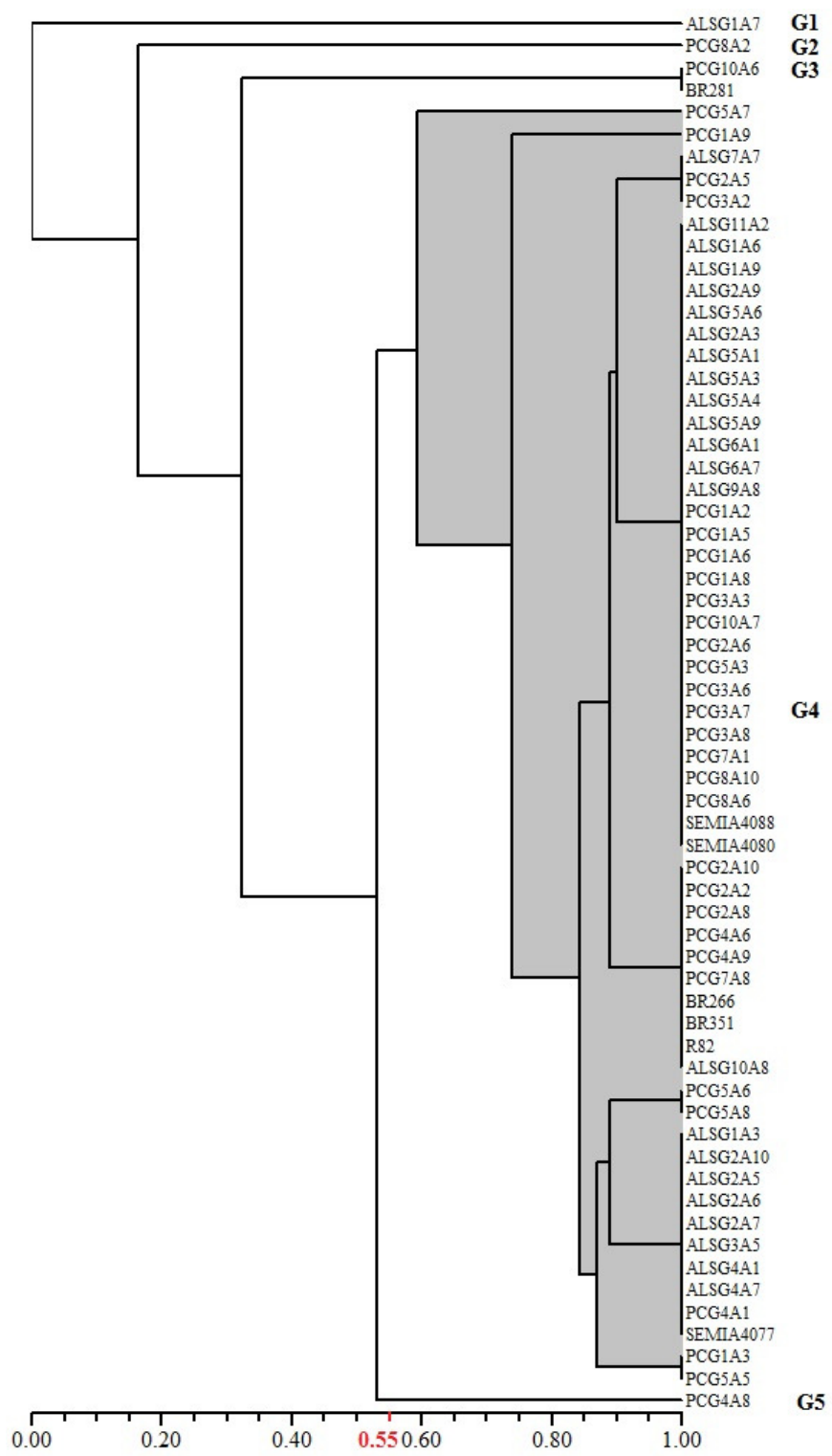

Figure 4. Similarity dendrogram constructed using Jaccard as similarity coefficient and UPGMA as grouping method, with basis on the use of different carbon sources by 55 rhizobia isolates obtained from soil samples of Paraná state.

In general, the largest number of isolates showed morphological characteristics similar to those of the standard strains of $R$. tropici (SEMIA 4077 and SEMIA 4088) and $R$. freirei (SEMIA 4080). Also, by the use of carbon source, most of the isolates grouped with the standard strains used as inoculant of the common bean (SEMIA 4080, SEMIA 4088 and SEMIA 4077), indicating that these isolates have metabolic characteristics similar to these strains, revealing great potential for use as inoculant for common bean. However, further studies must be carried out under field conditions to confirm the potential of these isolates to promote gain in growth and grain production of the common bean.

\section{CONCLUSIONS}

About $75 \%$ of the isolates show typical morphologic characteristics of Rhizobium strains;

Most of the isolates group with the standard strains of Rhizobium tropici and $R$. freirei, used in Brazil as commercial inoculant for the common bean; 
Morphophysiological characterization...

The isolates from Goiás and Minas Gerais soils show higher metabolic diversity compared to those from Paraná soils.

\section{ACKNOWLEDGMENTS}

The research was partialy funded by the CNPq (Conselho Nacional de Desenvolvimento
SAMPAIO, F. B.; KNUPP, A. M.; FERREIRA, E. P. B.

Científico e Tecnológico, Brazil), grant number 562563/2010-5. Enderson P. de B. Ferreira is also research fellow from $\mathrm{CNPq}$, grant number 310059/2013-5. The authors also thanks to Mr. Richard Melton for grammar review of the manuscript.

RESUMO: O objetivo deste trabalho foi caracterizar, com base em características morfológicas e quanto ao uso de fontes de $\mathrm{C}$, isolados de rizóbio obtidos de genótipos silvestres de feijoeiro-comum cultivados em amostras de solo dos Estados de Goiás, Minas Gerais e Paraná. A partir das informações foram geradas matrizes de similaridade, usadas para análise de agrupamento por dendrogramas de similaridade, com base no coeficiente de Jaccard. Foram obtidos 523 isolados com predominância de isolados que acidificaram o meio de cultivo e de crescimento rápido, sendo que os provenientes de solos de Araucária e Prudentópolis produziram maior quantidade de muco que os de Jussara, Nova Veneza, Uberlândia e Unaí. Os isolados de rizóbios obtidos de solos do estado de Goiás e Minas Gerais apresentaram maior diversidade fenotípica do que aqueles oriundos de solos do Paraná. A análise de uso de fontes de C revelou que os isolados de rizóbios obtidos de solos do estado de Goiás apresentaram maior diversidade metabólica. De forma geral, a maior parte dos isolados agrupou com as estirpes-padrão, especialmente com as estirpes de Rhizobium tropici e R. freirei usadas como inoculante do feijoeiro-comum.

PALAVRAS-CHAVE: Phaseolus vulgaris. FBN. Caracterização morfológica. Uso de fontes de C.

\section{REFERENCES}

ALVES, J. B. Seleção de rizóbios para trevo branco. 2005. 68p. Dissertação (Mestrado em Agronomia) Curso de Pós-Graduação em Ciência do Solo, Universidade Federal do Rio Grande do Sul, Porto Alegre.

BUILES, V. H. R.; PORCH, T. G.; HARMSEN, E. W. Genotypic differences in water use efficiency of common bean under drought stress. Agronomy Journal, Madison, v. 103, n. 4, p. 1206-1215, 2011. http://dx.doi.org/10.2134/agronj2010.0370

CASTELlANE, T. C. L.; LEMOS, E. G. M. Composição de exopolissacarídeos produzidos por estirpes de rizóbios cultivados em diferentes fontes de carbono. Pesquisa Agropecuária Brasileira, Brasília, v. 42, n. 10, p. 1503-1506, 2007. http://dx.doi.org/10.1590/S0100-204X2007001000019

CHAGAS JUNIOR, A. F.; OLIVEIRA, L. A. de; OLIVEIRA, A. N. Caracterização fenotípica de rizóbios nativos isolados de solos da Amazônia e eficiência simbiótica em feijão caupi. Acta Scientiarum Agronomy, Maringá, v. 32, n. 1, p. 161-169, 2010. http://dx.doi.org/10.4025/actasciagron.v32i1.900

CIAT - Centro Internacional de Agricultura Tropical. Programa de recursos genéticos.<http://isa.ciat.cgiar.org/urg/showbsearchacc.do;jsessionid=31C48575935965DC47B038A344528E6 7?type $=$ search\&by=accesion\&collection=bean\&new=new\&category=.>. 05 de Jun. 2015.

COUTINHO, H. L. C.; OLIVEIRA, V. M.; LOVATO, A.; MAIA, A. H. N.; MANFIO, G. P. Evaluation of the diversity of rhizobia in Brazilian agricultural soils cultivated with soybeans. Applied Soil Ecology, Amsterdam, v. 13, n. 2, p. 159-167, 1999. http://dx.doi.org/10.1016/S0929-1393(99)00031-1

DALL'AGNOL, R. F.; RIBEIRO R. A.; ORMEÑO-ORRILLO, E.; ROGEL, M. A.; DELAMUTA, J. R.; ANDRADE, D. S.; MARTÍNEZ-ROMERO, E.; HUNGRIA, M. Rhizobium freirei sp. nov., a symbiont of Phaseolus vulgaris that is very effective at fixing nitrogen. International Journal of Systematic and Evolutionary Microbiology, Reading, v. 63, n. 11, p. 4167-4173, 2013. http://dx.doi.org/10.1099/ijs.0.0529280 
FAO, Food and Agriculture Organization of the United Nations. Statistic Division. Disponível em: <http://faostat3.fao.org/browse/Q/QC/E>. Acesso em: 12 mar. 2015.

FERREIRA, E. P. B.; DUSI, A. N.; XAVIER, G. R.; RUMJANEK, N. G. Rhizosphere bacterial communities of potato cultivars evaluated through PCR-DGGE profiles. Pesquisa Agropecuária Brasileira, Brasília, v. 43, n. 5, p. 605-612, 2008. http://dx.doi.org/10.1590/S0100-204X2008000500008

FRED, E. B.; WAKSMAN, S. A. Laboratory manual of general microbiology - with special reference to the microorganisms of the soil. New York: McGraw-Hill Book Company, 1928. 145p.

HUNGRIA, M. Coleta de nódulos e isolamento de rizóbio. In: HUNGRIA, M.; ARAÚJO, R. S. (Ed.). Manual de métodos empregados em estudos de microbiologia agrícola. Brasília-DF: EMBRAPA-SPI; Santo Antônio de Goiás: Embrapa Arroz e Feijão, 1994. p. 45-61. (EMBRAPA-CNPAF. Documentos. 46).

HUNGRIA, M.; ANDRADE, D. S.; CHUEIRE, L. M. O.; PROBANZA, A.; GUTTIERREZ-MAÑERO, F. J.; MEGÍAS, M. Isolation and characterization of new efficient and competitive bean (Phaseolus vulgaris L.) rhizobia from Brazil. Soil Biology and Biochemistry, Oxford, v. 32, p. 1515-1528, 2000.

http://dx.doi.org/10.1016/S0038-0717(00)00063-8

HUNGRIA, M.; VARGAS, M. A. T.; ARAÚJO, R. S. Fixação biológica do nitrogênio em feijoeiro: In: VARGAS, M. A. T.; HUNGRIA, M. (Ed.). Biologia dos solos dos cerrados. Planaltina: EMBRAPA-CPAC, 1997, p.189-294.

IBGE - Instituto Brasileiro de Geografia e Estatísitca. Levantamento sistemático da produção Agrícola, v. 29, n. 1, 83p. 2015, Disponível em: <

ftp://ftp.ibge.gov.br/Producao_Agricola/Levantamento_Sistematico_da_Producao_Agricola_\%5Bmensal\%5D/ Fasciculo/lspa_201501.pdf>. Acesso em: 24 mar. 2015.

MARQUINA, M. E.; GONZALEZ, N. E.; CASTRO, Y. Caracterización fenotípica y genotípica de doce rizobios aislados de diversas regiones geográficas de Venezuela. Revista de Biologia Tropical, San Jose, v. 59, n. 3, p.1017-1036, 2011. http://dx.doi.org/10.15517/rbt.v0i0.3375

MEDEIROS, E. V.; MARTINS, C. M.; LIMA, J. A. M.; FERNANDES, Y. T. D.; OLIVEIRA, V. R.; BORGES, W. L. Diversidade morfológica de rizóbios isolados de caupi cultivado em solos do estado do Rio Grande do Norte. Acta Scientiarum Agronomy, Maringá, v.31, n.3, p.529-535, 2009.

http://dx.doi.org/10.4025/actasciagron.v31i3.793

MOSTASSO, L.; MOSTASSO, F. L.; DIAS, B. G.; VARGAS, M. A. T.; HUNGRIA, M. Selection of bean (Phaseolus vulgaris L.) rhizobial strains for the Brazilian Cerrados. Field Crops Research, Amsterdam, v. 73, n. 2-3, p. 121-132, 2002. http://dx.doi.org/10.1016/S0378-4290(01)00186-1

OLIVEIRA, J. P.; GALLI-TERASAWA. L. V.; ENKE, C. G.; CORDEIRO, V. K.; ARMSTRONG, L. C. T.; HUNGRIA, M. Genetic diversity of rhizobia in Brazilian oxisol nodulating Mesoamerican and Andean genotypes of common bean (Phaseolus vulgaris L.). World Journal of Microbiology and Biotechnology, Berlin, v.27, n.3, p.643-650, 2011. http://dx.doi.org/10.1007/s11274-010-0501-9

PINTO, F. G. S.; HUNGRIA, M.; MERCANTE, F. M. Polyphasic characterization of Brazilian Rhizobium tropici strains effective in fixing $\mathrm{N}_{2}$ with common bean (Phaseolus vulgaris L.). Soil Biology and Biochemistry, Oxford, v. 39, n. 08, p. 1851-1864, 2007. http://dx.doi.org/10.1016/j.soilbio.2007.01.001

SILVA, V. N.; SILVA, L. E. S. F.; FIGUEIREDO, M. V. B.; CARVALHO, F. G.; SILVA, M. L. R. B.; SILVA, A. J. N. Caracterização e seleção de populações nativas de rizóbios de solo da região semi-árida de Pernambuco. Pesquisa Agropecuária Tropical, Goiânia, v. 37, n. 1, p. 16-21, 2007.

VARGAS, M. A. T.; HUNGRIA, M. Biologia dos solos dos Cerrados. Planaltina: EMBRAPA-CPAC, 1997. $524 \mathrm{p}$. 